IZA DP No. 7670

\title{
Catastrophic Job Destruction
}

Anabela Carneiro

Pedro Portugal

José Varejão

October 2013

Forschungsinstitut

zur Zukunft der Arbeit Institute for the Study

of Labor 


\title{
Catastrophic Job Destruction
}

\author{
Anabela Carneiro \\ Universidade do Porto \\ and CEF.UP \\ Pedro Portugal \\ Banco de Portugal, \\ NOVA School of Business and Economics and IZA \\ José Varejão \\ Universidade do Porto, \\ CEF.UP and IZA
}

\section{Discussion Paper No. 7670 \\ October 2013}

IZA

\author{
P.O. Box 7240 \\ 53072 Bonn \\ Germany
}

\author{
Phone: +49-228-3894-0 \\ Fax: +49-228-3894-180 \\ E-mail: iza@iza.org
}

\begin{abstract}
Any opinions expressed here are those of the author(s) and not those of IZA. Research published in this series may include views on policy, but the institute itself takes no institutional policy positions. The IZA research network is committed to the IZA Guiding Principles of Research Integrity.

The Institute for the Study of Labor (IZA) in Bonn is a local and virtual international research center and a place of communication between science, politics and business. IZA is an independent nonprofit organization supported by Deutsche Post Foundation. The center is associated with the University of Bonn and offers a stimulating research environment through its international network, workshops and conferences, data service, project support, research visits and doctoral program. IZA engages in (i) original and internationally competitive research in all fields of labor economics, (ii) development of policy concepts, and (iii) dissemination of research results and concepts to the interested public.
\end{abstract}

IZA Discussion Papers often represent preliminary work and are circulated to encourage discussion. Citation of such a paper should account for its provisional character. A revised version may be available directly from the author. 


\section{ABSTRACT}

\section{Catastrophic Job Destruction*}

In this article we study the resilience of the Portuguese labor market, in terms of job flows, employment and wage developments, in the context of the current recession. We single out the huge contribution of job destruction, especially due to the closing of existing firms, to the dramatic decline of total employment and increase of the unemployment rate. We also document the very large increase in the incidence of minimum wage earners and nominal wage freezes. We explore three different channels that may have amplified the employment response to the great recession: the credit channel, the wage rigidity channel, and the labor market segmentation channel. We uncover what we believe is convincing evidence that the severity of credit constraints played a significant role in the current job destruction process. Wage rigidity is seen to be associated with lower net job creation and higher failure rates of firms. Finally, labor market segmentation seems to have favored a stronger job destruction that was facilitated by an increasing number of temporary workers.

JEL Classification: E24, J23, J63

Keywords: job destruction, credit constraints, wage rigidity, segmentation

Corresponding author:

Pedro Portugal

Banco de Portugal

Av. Almirante Reis, 71

1150-165 Lisboa

Portugal

E-mail: jppdias@bportugal.pt

\footnotetext{
* The authors would like to thank Albert Jaeger, António Antunes, Fernando Martins, Francesco Franco, Paulo Júlio and Sónia Félix for help with data. Helpful comments by Albert Jaeger, Alexander Hijzen, Daphne Nicolitsas, Lucrezia Reichlin, Nuno Alves, Pedro Martins and participants at the Euro Crisis Conference, Bank of Greece, Athens, and OECD Workshop on Labour Market Resilience are gratefully acknowledged. The authors also thank Lucena Vieira for excellent computer assistance. All the views expressed in this article remain with the authors and do not necessarily represent the views of the Bank of Portugal or the Eurosystem.

CEF.UP - Centre for Economics and Finance at the University of Porto is funded by Fundação para a Ciência e Tecnologia under Programa Compete - project reference: PEst-C/EGE/UI4105/2011.
} 


\section{Introduction}

In Economics, resilience is typically defined as the rate at which an economic system responds to an exogenous shock. It is greater when the response preserves or minimizes changes to the pre-existing status quo. Hence, resilience may be quantified as the cumulative loss in some variable of interest and/or documented with the depth of structural reforms triggered by the shock. ${ }^{1}$ Given its implications for aggregate welfare, labor market resilience - defined as 'the extent to which labor markets weather economic downturns with limited social costs' (OECD, 2012: 57) - is of special interest.

The depth of the 2008-2009 economic crisis put the resilience of labor markets across the globe to the test and provided us with the ideal setting for studying how labor markets respond to shocks. In its 2012 Employment Outlook Report, the OECD concluded that labor market institutions crucially shaped the response to the global crisis with coordinated bargaining increasing resilience and the spread of temporary employment reducing it (OECD, 2012: 55). As the global crisis kicked in, substantial differences across countries both in terms of labor market institutions and economic fundamentals were already apparent. It is clear that some economies were better-equipped to deal with the consequences of the recession than others.

In this paper, we focus on the case of Portugal which is of interest for two major reasons. First, despite all the regulatory changes implemented since 2002, the Portuguese labor market is, according to the OECD index of employment protection legislation strictness, an extreme case of labor market regulation. Second, even before the recession set in, the Portuguese economy was already facing severe macroeconomic imbalances that amplified the domestic impact of the international recession. Portugal clearly stands out as one of the OECD countries most ill-equipped to weather the effects of the current recession.

Our aim is to analyze how the Portuguese labor market responded to the re-

\footnotetext{
${ }^{1}$ One of the definitions of resilience used in Ecology focuses on the magnitude of a disturbance that can be absorbed before the system changes its structure, the greater that magnitude is the more resilient the system is.
} 
cession, focusing on the employment and wage response to the great recession and considering three different channels that may have amplified the employment response: the credit channel, the wage rigidity channel, and the labor market segmentation channel. ${ }^{2}$ In the empirical part of the article we use microdata from the Personnel Records database (Quadros de Pessoal), henceforth QP, that are available for the years 1985 to 2010. These data are linked employer-employee data. They do not have information on financial variables. For that reason, to analyze the importance of the credit channel we use data from the Simplified Business Information database (Informação Empresarial Simplificada), henceforce IES, available for the years 2005 to $2011 .^{3}$

The article is organized as follows. Section 2 gives an overview of the evolution of the Portuguese economy and the Portuguese labor market over the last 20 years. In Section 3 the role that each transmission channel played during the current recession is analysed. Section 4 concludes.

\section{Background information on the Portuguese case}

\subsection{The macroeconomy}

When the 2008-2009 recession hit Portugal, the Portuguese economy was already facing severe macroeconomic imbalances. Blanchard (2007) offers a very precise diagnosis of the country's economic problems at the onset of the recession: 'Portugal is in serious trouble. Productivity growth is anemic. Growth is very low. The budget deficit is large. The current account deficit is very large. In the absence of policy changes, the most likely scenario is one of competitive disinflation, a period of sustained high unemployment until competitiveness has been reestablished'.

The diagnosis proved accurate (Figure 1): the large decrease in nominal interest rate (1995-2001) opened the way to an increase in debt-funded private expenditure

\footnotetext{
${ }^{2}$ Other mechanisms are, surely, at work. The role of fiscal multipliers (Blanchard and Leigh, 2013), the consequences of the combination of generous unemployment benefits with strict employment protection (the unemployment time-bomb suggested in Ljungqvist and Sargent (1998), or the persistence of unemployment generated by hysteresis (Blanchard and Summers, 1986) certainly deserve a deep analysis. With the current available microdata, however, this is beyond the scope of this study

${ }^{3}$ For a description of the data, see Appendix 1. Whenever appropriate we also use data from a random sample extracted from Social Security records.
} 
that originated an increase in labor demand and a 6 percent annual average increase of nominal wages and an inflation rate of 4 percent. Competitiveness vis-à-vis the eurozone countries rapidly and significantly deteriorated (see Franco, 2013).

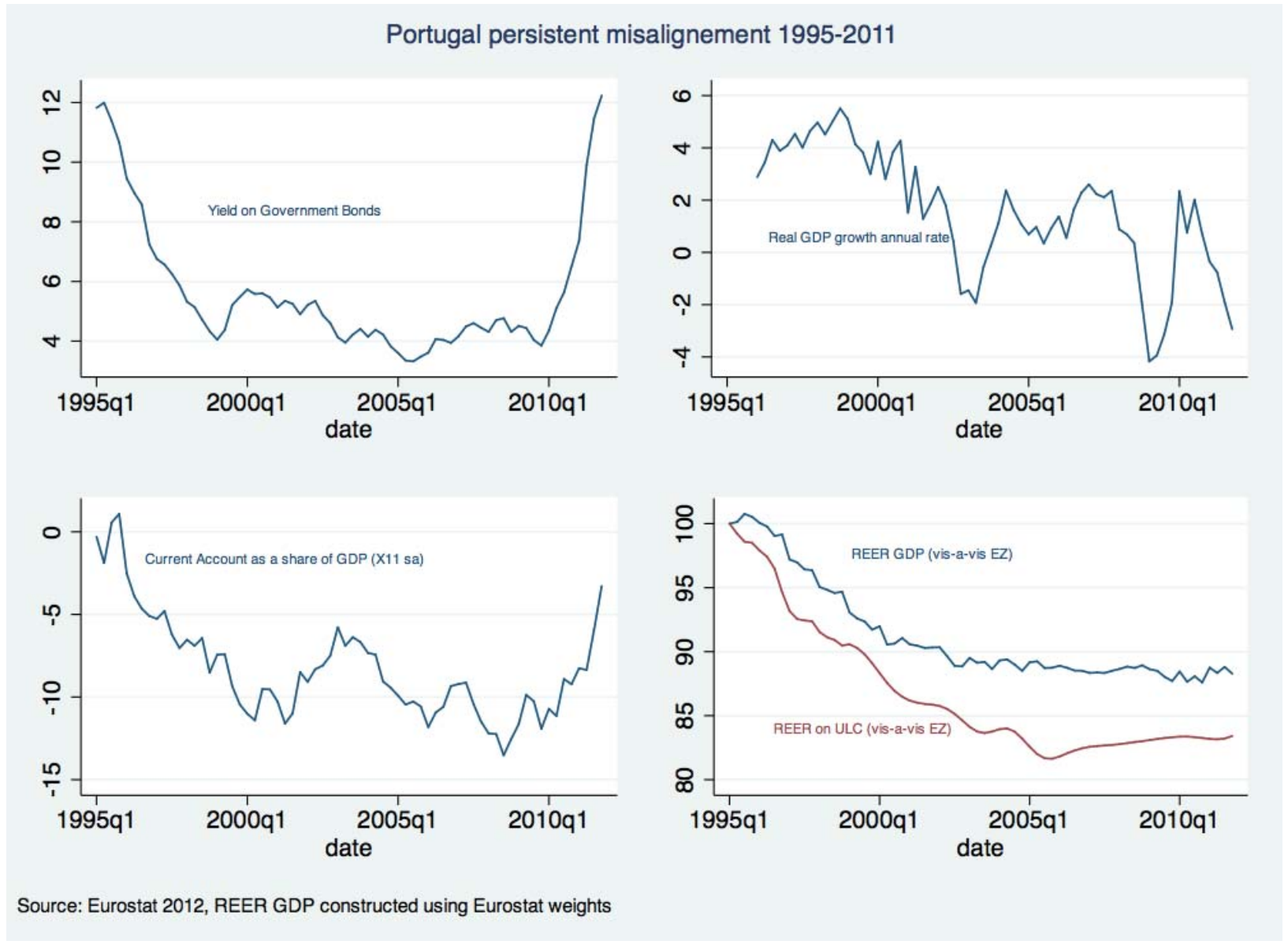

Figure 1: Portuguese Macroeconomic Imbalances

Source: Franco (2013).

In such a context the government's immediate response to the international financial crisis was driven by two objectives: to maintain the stability of the Portuguese financial sector, and to smooth the domestic effects of the crisis. The combined effects of the increased public spending and reduced public revenue (due to the activation of automatic stabilizers) made access to international financial markets increasingly more difficult, and eventually (May 2011) led to a rescue 
plan agreed between the Portuguese government, the European Union, the European Central Bank, and the International Monetary Fund. Structural reforms are one essential ingredient of this plan, including the reform of a large number of institutions, namely labor market institutions.

The implementation of the said plan in the context of a global recession originated a severe domestic recession that generated historically high unemployment rates - in the first quarter of 2013 the unemployment rate reached 17.7 percent, which nearly tripled the average rate of unemployment that prevailed for decades (see Figure 2).

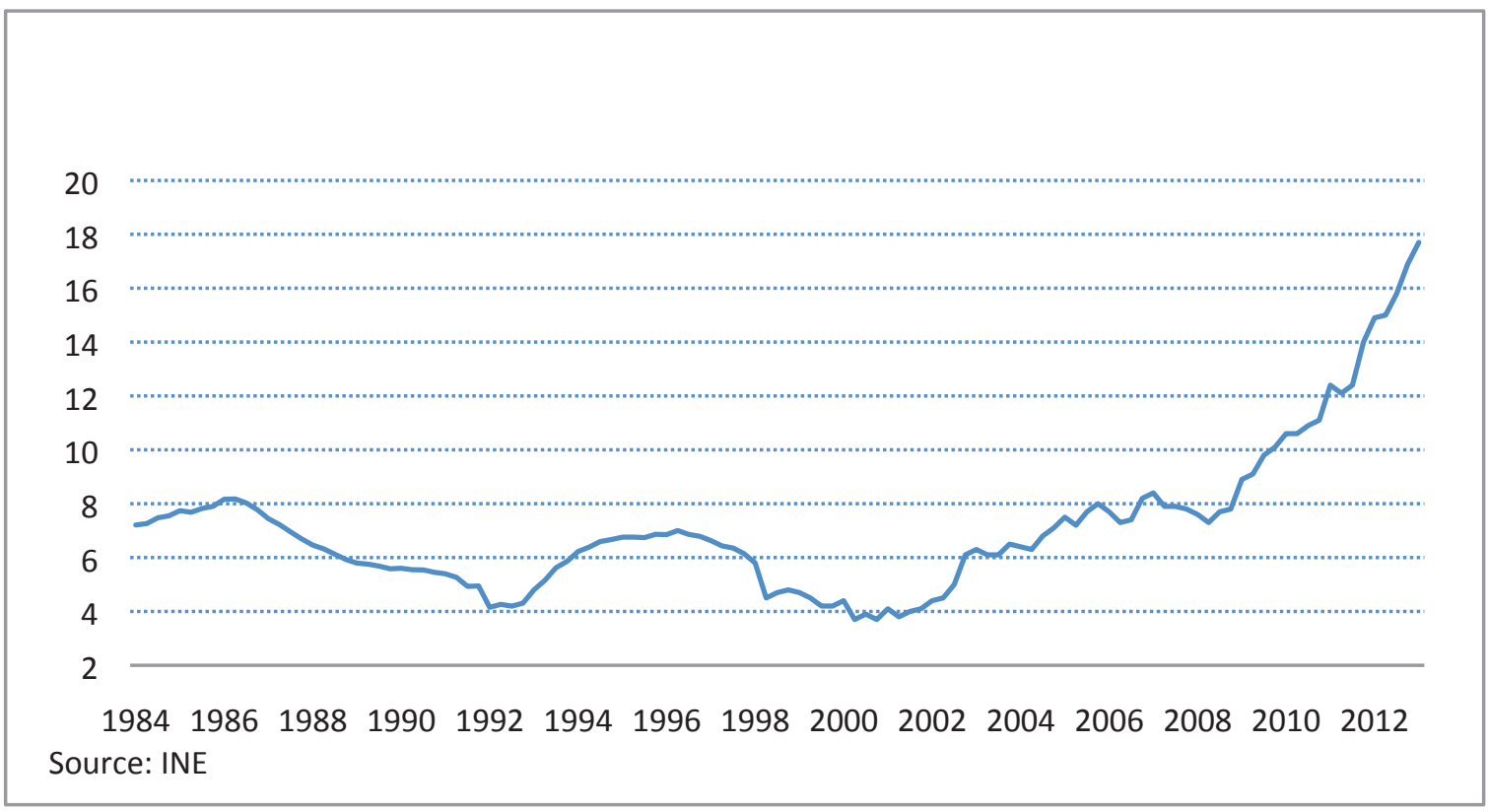

Figure 2: The Evolution of the Unemployment Rate (in \%) - 1984-2012

Source: INE - Labour Force Survey.

Four years into the recession the unemployment rate is ten percentage points higher than it was at the onset and employment fell by more than 12 percentage points. This evolution reflects not only the depth of the recession, but also the underlying macroeconomic dynamics.

The sharp fall of total employment that characterizes this recession can be decomposed into two sources: the employment variation accounted for by continuing 
firms and the employment variation accounted for by the entry and exit of firms. Figure 3 shows that, as the recession hit in 2008-09, employment creation fell along both margins: the level of job creation by expanding firms dropped in 2009 to a level that is similar to that observed in 1993, whereas job creation by newly-created firms in 2009 equaled the period's minimum. 

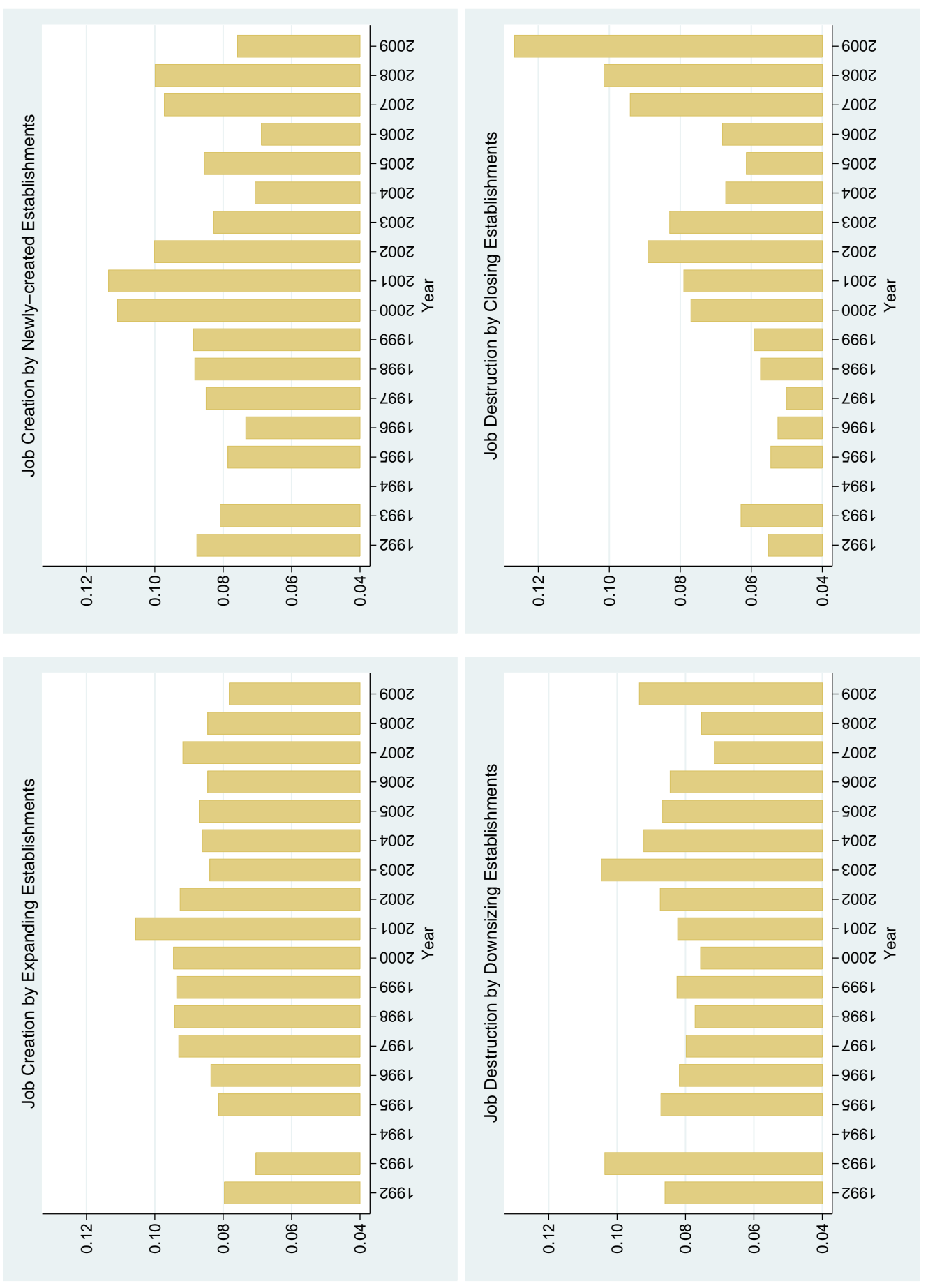

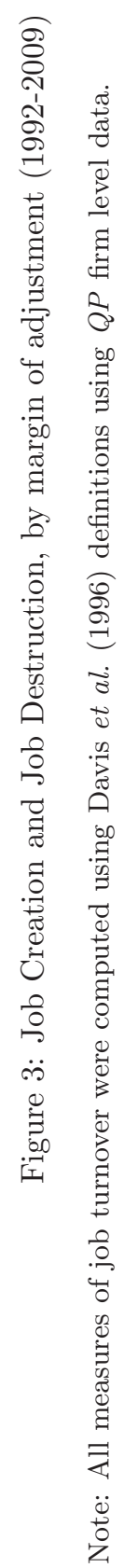


However, it is along the destruction margin that, relatively to past recessions, the employment path during this recession shows the most striking differences. Job destruction by firms that continue in operation increased very significantly in 2009, but not more so than during the 1993 recession. Yet, along the exit margin, we do observe an unprecedented massive and immediate amount of job destruction. From 2007 to 2009, the rate of job destruction by closing firms increased 2.6 p.p. - in 2009, firms that closed down destroyed 6.9 percent of the corresponding average number of jobs that existed in that year. Over the entire period analyzed, firm shutdowns accounted, on average, for 36.4 percent of total job destruction. However, as the current recession sank in, the share of closings in the total increased sharply, from 37.5 percent in 2006 to 45.6 percent in 2009. In the same year, the share of job turnover accounted for by the turnover of firms was 40.6 percent, 5 p.p. above its pre-recession (2006) level.

Hence, if one wants to understand the causes of the employment crisis it is essential to look at both the intensive (downsizing) and extensive (exit) margins of firm adjustment. Firm closings are a major ingredient of the current situation, and much more so than they were in past recessions.

\subsection{The labor market}

\subsubsection{Labor market flows}

Strict job security rules have been blamed for low intensity transitions between employment and unemployment, and very long unemployment spells (Blanchard and Portugal, 2001).

Data from the European Household Panel shows that Portugal has the lowest arrival rate of job offers among all the countries represented in the panel (Jolivet et al. 2006; Addison et al., 2009). The evidence available (Torres, 2010, Elsby et al., 2008) also indicates that job separation and job finding probabilities are very low, with job separations being essentially acyclical whereas the probability of job finding is strongly cyclical. However, Torres (2010), using Employment Survey data finds evidence of an upward shift in job separation probabilities in 
more recent years.

During the nineties, the Portuguese labor market was already conspicuous for exhibiting high mean unemployment duration. In comparison with the US, Portugal presented three times longer unemployment durations. During the second half of the 2000s, mean unemployment duration increased significantly (from a minimum of less than 14 months in 2003) to all-time high values in 2013 (above 23 months).

Properly accounting for the fact that only unemployment spells in progress are sampled, and assuming stationarity of unemployment inflows it is estimated that mean unemployment duration increased by 68.7 percent over the period and that the fraction of long-term unemployed (those with a low hazard rate) changed from 25,3 percent to near 70 percent. ${ }^{4}$ Since the unemployment rate was roughly multiplied by a factor of three during the same period, this means that inflows into unemployment increased by around 78 percent.

\begin{tabular}{rrc} 
TABLE 1: DISTRIBUTION OF UNEMPLOYMENT DURATION \\
\hline \hline & \multicolumn{2}{c}{ Exponential Mixture } \\
& $2001-2002$ & $2011-2012$ \\
\hline \hline Short-term $\lambda_{1}$ & $0.158^{*}$ & $0.167^{*}$ \\
& $(0.009)$ & $(0.013)$ \\
Long-Term $\lambda_{2}$ & $0.045^{*}$ & $0.044^{*}$ \\
& $(0.001)$ & $(0.001)$ \\
Fraction of long-term & $0.253^{*}$ & $0.696^{*}$ \\
\hline Mean unemployment duration & 10.4 months & 17.5 months \\
$\mathrm{N}$ & 7045 & 21260 \\
\hline \hline
\end{tabular}

Source: INE-Labour Force Survey.

In such a setting, unemployment protection will tend to cushion the pain associated with the joblessness experience, that is severe both due to the long duration of unemployment spells and to significant wage cuts after reemployment (Raposo, et al., 2013). Yet, unemployment protection also generates an even steeper fall in the transition from unemployment into employment. Addison and Portugal (2008) analyzed pre-1998 transitions from unemployment to employment using a

\footnotetext{
${ }^{4}$ All these results were obtained from the estimation of a discrete mixture exponential model, accounting for censored durations and for stock sampling, on data from the INE employment survey records for the period 2001-2002 until and 2011-2012.
} 
regression discontinuity design that fits the characteristics of the unemployment insurance at that time when the maximum period of potential benefit depended in a deterministic way on the age of the unemployed person. The authors find that a large proportion of the population (44.5\%) never makes a transition out of unemployment, but they also conclude that longer maximum potential duration of benefits translate into much lower escape rates.

\subsubsection{Institutional Wage Setting}

Wage setting in Portugal is dominated by the presence of mandatory minimum wages and by the widespread use of government extensions of sectoral agreements. Collective bargaining differs from that in other nations by virtue of its fragmentation and extent of multiunionism.

There is a modicum of firm-level bargaining but formally decentralized bargaining of this nature is the exception rather than the rule - covering less than 10 percent of the workforce - and often taking place in large enterprises that were formerly part of the public sector. Sectoral agreements, conducted by employer and union confederations, may cover a wide range of industry specific occupations but the system does not rule out overlapping collective agreements, such that a single enterprise may be covered by two or more agreements depending on the union affiliation of its workers. Overall, coverage of collective agreements in the Portuguese private sector is above 90 percent.

Collective agreements are at once extensive and general. They are extensive insofar as they cover many categories of workers. They are general in that they set only minimum conditions of which the most important is base level monthly wages - though others include normal working hours and overtime pay. The focus is upon wage floors rather than anticipated wage growth that in some centralized bargaining regimes (e.g. Sweden) is then incorporated into sectoral agreements. In consequence, employers have freedom of maneuver to tailor remuneration to their prevailing economic circumstance (see Cardoso and Portugal, 2005).

The most relevant mechanism shaping the formation of wages is the system- 
atic extension of industry-wide agreements by the Ministry of Employment. Even though by law the collective agreement only binds the trade union members and the employer associations' affiliated firms that are parties to the agreement, there is no legal mechanism that obliges the trade unions and the employers association to reveal their constituency. This legal conundrum is almost always circumvented by extending the agreement to the whole sector through the use "portarias de extensão". This means that even wage agreements reached by trade unions and employers' associations with very low representation have a strong impact in setting wage floors. Indeed, in any given year, collective bargaining sets around 30,000 minimum wages that correspond to 30,000 job-titles.

These minima apply if they are set over and above the wage floors set under national minimum wage machinery that was established in 1974. National legal minimum wages and pervasive wage floors set by collective bargaining coupled with the legal prohibition of nominal wage cuts (that survives since the 1950s) creates a de facto situation of extreme nominal wage rigidity. However, in a high inflation regime, this restriction proved to be not binding in real terms as real salary concession is achieved by raising nominal wages at a rate below the inflation rate, and for firms paying wages above the corresponding new minimum, by reducing the wage drift.

In such a setting, the higher the inflation rate, the more leeway on wages is available for companies. However, in a low-inflation regime nominal wage rigidity may stop companies from adjusting to negative shocks to the demand for their products through wage manipulation. ${ }^{5}$ In situations like this, employers' response on the wage margin is limited to the possibility of reducing the wage drift or going for the minimum nominal wage increase possible, ultimately freezing wages. Hence, in a low-inflation regime, negative shocks are expected to shift the employment distribution of nominal wage adjustment towards zero, the magnitude of real wage adjustment being conditional on the inflation rate. This is, in fact, what is observed during the current recession, with the wage response being characterized as in the

\footnotetext{
${ }^{5}$ Extra leeway for adjustment could also be obtained from using the structure of total pay, which is made up of base pay, regular and occasional payments and overtime, to reduce wages.
} 
past by no (or limited) nominal negative variations (measured from base pay), but a much higher likelihood than in the past that wage variations are nil; there is also a salient move towards zero in the distribution of wage variations, corresponding approximately to the expected inflation rate and accentuating even more the low distribution spread.

Furthermore, mounting evidence indicates that the cyclicality of real wages declined after the accession to the Euro area (Portugal et al., 2012). With due proviso for the care to be taken over the interpretation of these results, owing to the uncertainty of the timeline associated with the measurement of the economic cycle, claim may naturally be made to the loss of real wage sensitivity as one of the mechanisms responsible, inter alia, for the Portuguese economy current macroeconomic imbalances (Blanchard, 2007).

\section{Transmission channels}

In previous sections we documented three main features of the current recession in Portugal: (i) severe credit constraints, (ii) limited real wage flexibility with nominal wage downwards rigidity, and (iii) labor market segmentation with an increasingly larger share of temporary contracts in total employment. Arguably, all these features have the potential to influence the employers' response to macroeconomic shocks. The purpose of this section is to analyze if and how they contributed to the massive destruction of jobs, i.e. if they acted as channels through which the effects of the financial crisis were transmitted to the labor market. We consider each transmission channel separately.

\subsection{The credit channel}

The unfortunate combination of the financial crisis, the sovereign debt crisis, and regulatory requirements of the international assistance program necessary to reestablish financial stability generated severe credit restrictions for the Portuguese non-financial firms. Figure 4 illustrates the decoupling of Portuguese interest rates

on new loans to firms from selected European economies (panel A) and the evolu- 

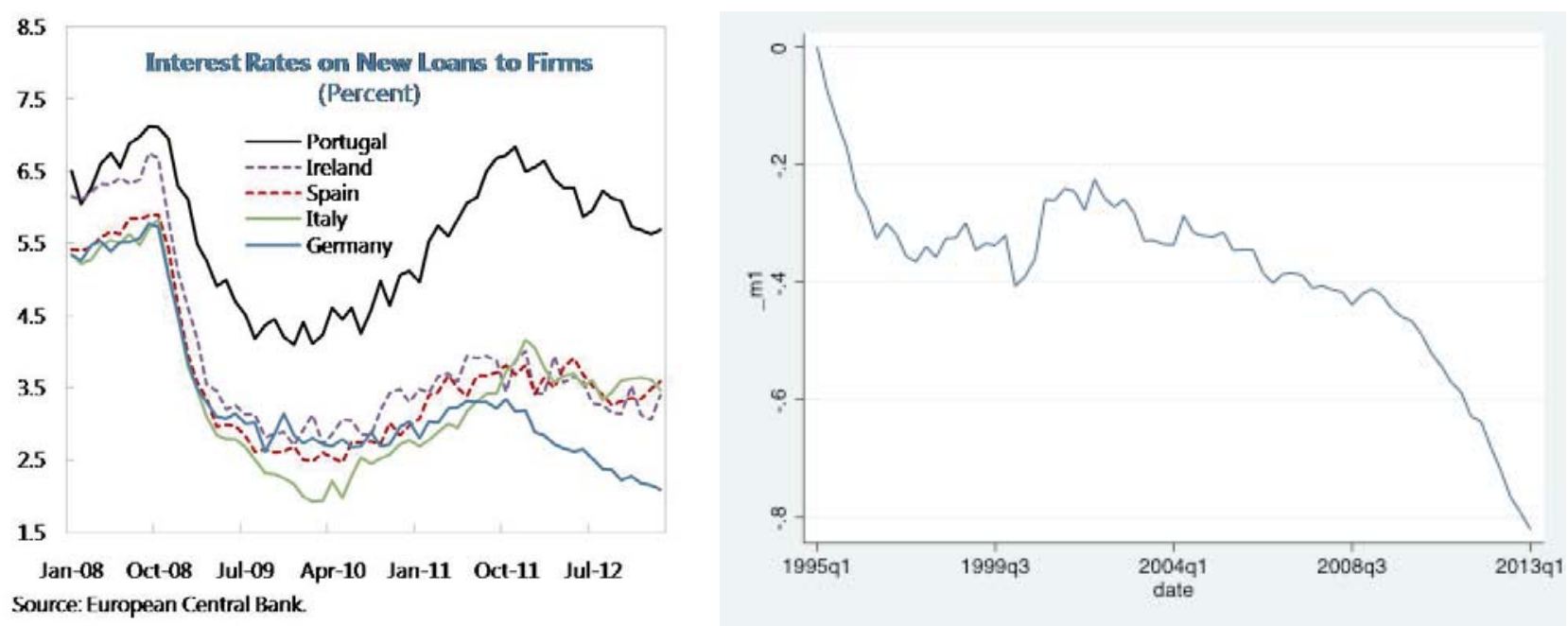

Figure 4: A. Interest Rate Fragmentation; B. Firms' Debt Levels

Note: Panel B plots the variation of firms' debt levels with respect to the 1st quarter of 1995 (on a logarithmic scale). Source: European Central Bank and IMF.

tion of the level of debt of Portuguese firms (panel B). ${ }^{6}$

From the figure, it is clear that since the begining of 2009 the Portuguese interest rates on new bank loans to firms are increasingly diverging from other European markets' levels (panel A) - the difference relatively to Germany, for example, more than tripled between January 2009 and January 2013. At the same time, the typical level of the firms debt decreased sharply (around 40 log points or 33 percent) since 2009 (panel B).

Regarding the credit channel, the question of interest is if (and how) the severe credit constraints faced by Portuguese firms may be linked to the destruction of jobs both at the intensive (i.e., by downsizing firms) and the extensive (i.e., by closing firms) margins. ${ }^{7}$ We proceed in two steps.

First, we estimate by pooled OLS a model of the determinants of net job creation $(N J C)$ at the firm level that includes a measure of firm-specific interest rates and outstanding debt, and a number of controls. The model is written as:

\footnotetext{
${ }^{6}$ The graph in panel B displays the evolution of quarterly fixed effects from a regression of the (log of) the level of debt that also includes firm-bank fixed effects.

${ }^{7}$ See Nickell and Nicolitsas (1999) for an early study of the relationship between financial pressure and employment.
} 


$$
\begin{array}{r}
N_{f t}=\alpha_{0}+\alpha_{1} \log \text { Sales }_{f t}+\alpha_{2} \log \text { Wages }_{f t}+\alpha_{3} \log _{\text {Capital }}+\alpha_{f t} \log T F P_{f t} \\
+\alpha_{5} \text { Debt }_{f t}+\delta_{t}+\xi_{t} r_{f t}+\epsilon_{f t}
\end{array}
$$

where Sales is the annual value of shipments, Wages is the firm-level annual labor costs per worker (the wage bill divided by the number of workers), Capital is the year-end value of the company's fixed assets, Debt is the total amount of outstanding debt as of the end of the year, and TFP is total factor productivity. ${ }^{8}$ $r$ is the firm-specific interest rate, computed as the ratio between total financial costs and debt stock. Subscript $f$ denotes the firm and subscript $t$ denotes the year. $\epsilon_{f t}$ is an idiosyncratic error term.

Equation 1 was estimated using IES data for manufacturing firms. Results, reported in Table 2, show that interest rates have a negative impact on the employment outcomes of surviving firms. More significantly, the magnitude of the negative effect of interest rates on employment increases sharply in 2010 and 2011.

\footnotetext{
${ }^{8}$ Total factor productivity is obtained as the sum of the firm fixed-effect and the residual in a two-factor (labor and capital) Cobb-Douglas production function.
} 
TABLE 2: DETERMINANTS OF NET JOB CREATION Pooled OLS regression (2006-2011)

\begin{tabular}{|c|c|}
\hline & Estimates \\
\hline log sales & $\begin{array}{l}0.053^{*} \\
(0.003)\end{array}$ \\
\hline log wages & $\begin{array}{r}-0.140^{*} \\
(0.007)\end{array}$ \\
\hline $\log$ capital & $\begin{array}{r}-0.052^{*} \\
(0.003)\end{array}$ \\
\hline total factor productivity & $\begin{array}{r}0.060^{*} \\
(0.005)\end{array}$ \\
\hline $\log$ debt & $\begin{array}{r}0.005^{*} \\
(0.001)\end{array}$ \\
\hline firm interest rate $* 2006$ & $\begin{array}{r}0.023 \\
(0.051)\end{array}$ \\
\hline firm interest rate $* 2007$ & $\begin{array}{r}0.038 \\
(0.037)\end{array}$ \\
\hline firm interest rate $* 2008$ & $\begin{array}{r}0.034 \\
(0.042)\end{array}$ \\
\hline firm interest rate $* 2009$ & $\begin{array}{r}-0.058 \\
(0.042)\end{array}$ \\
\hline firm interest rate $* 2010$ & $\begin{array}{r}-0.184^{*} \\
(0.051)\end{array}$ \\
\hline firm interest rate $* 2011$ & $\begin{array}{r}-0.221^{*} \\
(0.054)\end{array}$ \\
\hline $\begin{array}{r}\text { Number of firms } \\
R^{2}\end{array}$ & $\begin{array}{r}90014 \\
0.064\end{array}$ \\
\hline \multicolumn{2}{|c|}{$\begin{array}{l}\text { Source: } I E S . \\
\text { The regression also includes five year dummies and a constant term. } \\
\text { Data are restricted to firms with at least one wage-earner with valid } \\
\text { i.e. non-missing and non-negative on value-added, capital and all } \\
\text { the other variables used to compute TFP and estimate the model. } \\
\text { Only firms with positive debt and debt service were sampled. } \\
\text { Firm-cluster robust standard errors in parentheses. }\end{array}$} \\
\hline
\end{tabular}

To consider the effect of credit constraints on the extensive margin we estimate a standard firm failure Probit model augmented to include the same two debt related variables: the firm-specific interest rate $(r)$ and the firm total amount of outstanding debt (Debt). The model writes as:

$$
\begin{aligned}
\operatorname{Prob}\left(\text { Exit }_{f t+1}=1\right)= & \Phi\left(\alpha_{0}+\alpha_{1} \log \text { Sales }_{f t}+\alpha_{2} \text { TPF }_{f}+\alpha_{3} \log \operatorname{Debt}_{f t}\right. \\
& \left.+\alpha_{4} \log \text { ages }_{f t}+\alpha_{5} \log \text { Wrker }_{f t}+\delta_{t}+\xi_{t} r_{f t}\right)
\end{aligned}
$$

where Exit $_{f t+1}$ is a dummy variable equal to 1 if firm $f$ exited at year $t+1$, and Workers refers to the year-average count of employees. All the other variables are defined as above. From the regression results in Table 3 it can be seen that 
higher (firm-level) interest rates are associated with higher probabilities of firms shutting-down, as expected. What seems to be worth noting is the evidence that the role of interest rates significantly aggravated after 2009, leading to a higher failure rates in 2009 and 2010.

\begin{tabular}{|c|c|c|}
\hline & \multicolumn{2}{|c|}{ Probit Regression } \\
\hline & Coefficients & Marginal effects \\
\hline \multirow[t]{2}{*}{ "log sales } & $-0.104^{*}$ & -0.008 \\
\hline & $(0.018)$ & \\
\hline \multirow[t]{2}{*}{ log wages } & $0.131^{*}$ & 0.01 \\
\hline & $(0.033)$ & \\
\hline \multirow[t]{2}{*}{ log employment } & $0.175^{*}$ & 0.013 \\
\hline & $(0.018)$ & \\
\hline \multirow[t]{2}{*}{ log capital } & $-0.144^{*}$ & -0.011 \\
\hline & $(0.011)$ & \\
\hline \multirow[t]{2}{*}{ total factor productivity } & $-0.293^{*}$ & -0.021 \\
\hline & $(0.017)$ & \\
\hline \multirow[t]{2}{*}{$\log$ debt } & $0.160^{*}$ & 0.012 \\
\hline & $(0.011)$ & \\
\hline \multirow[t]{2}{*}{ firm interest rate $* 2006$} & $1.771^{*}$ & 0.129 \\
\hline & $(0.260)$ & \\
\hline \multirow[t]{2}{*}{ firm interest rate $* 2007$} & $1.274^{*}$ & 0.093 \\
\hline & $(0.245)$ & \\
\hline \multirow[t]{2}{*}{ firm interest rate $* 2008$} & $1.419^{*}$ & 0.104 \\
\hline & $(0.223)$ & \\
\hline \multirow{2}{*}{ firm interest rate $* 2009$} & $2.008^{*}$ & 0.147 \\
\hline & $(0.220)$ & \\
\hline \multirow[t]{2}{*}{ firm interest rate $* 2010$} & $3.037^{*}$ & 0.222 \\
\hline & $(0.218)$ & \\
\hline Number of firms & 755 & \\
\hline Source: $I E S$. & & \\
\hline The regressio & L & nstan \\
\hline
\end{tabular}

\subsection{The wage rigidity channel}

In section 2 we described wage setting mechanisms in Portugal and argued that the increase in the percentage of the total number of employees that are paid at the minimum wage and the obstacles to reducing nominal wages below what is collectively agreed upon led to the freezing of nominal wages of increasing numbers of workers, wage freezes being the only feasible alternative response to adverse demand shocks on the wage margin. 
All the evidence indicates virtually non-existent negative nominal wage variation until 2009 but a growing share of zero wage variation (wage freezes) - in 2009, wage freezes represented nearly 40 percent of all observations (figure 9 in Appendix 2 ). In the same period, the distribution of the variation of the wage drift becomes unequivocally sparser to the right of zero, and more populated to the left (figure 10, Appendix 2). ${ }^{9}$

In figure 5 we reproduce the information on wage freezes plotted in figure A1 (Appendix 2) obtained from QP data for the years 2003-2009 (panel A), and complement that with similar information from Social Security Records for 20092012 (panel B).
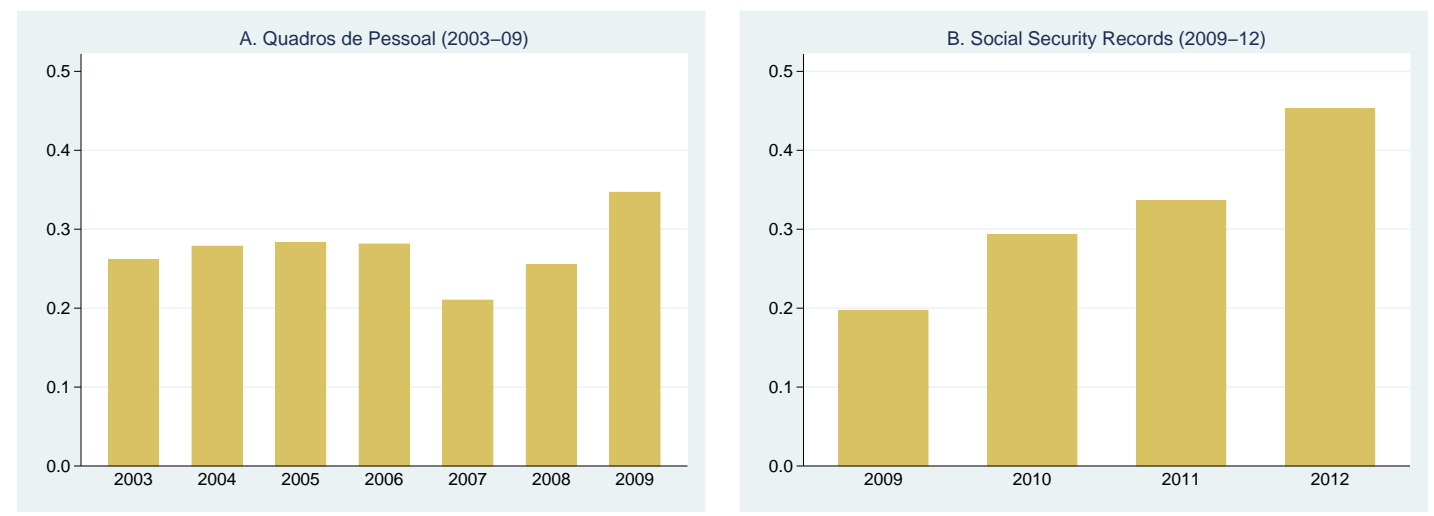

Figure 5: Incidence of Wage Freezes Among Job Stayers

Note: Wage freezes are defined as zero wage variation from one year to the next. In Panel B we present the results kindly provided by the Ministry of the Economy obtained from a representative sample of individuals that pay contributions to the public Social Security pension system (18,650 observations per year). Only wage-earners receiving full payment were considered. Annual wage variations were computed with January data.

Although the figures in the two panels are not comparable in levels, they show

\footnotetext{
${ }^{9}$ Other than non-compliance with the legal ban on nominal wage cuts, some factors, most notably, the reduction of the number of normal hours of work (e.g. moving from full-time to part-time work or reducing the duration of part-time work) may generate nominal negative variation of monthly wages. Besides, there is evidence obtained from Social Security records that in 2012 the incidence of negative variation of nominal wages for continuing matches is not negligible. We do note this fact even though it is not clear how much of this variation is due to the wage cut of civil servants with individual contracts and workers employed in state-owned firms implemented in 2011 , or to other special circumstances, including possibly wage arrrears. The same data also indicate a very sharp increase of the incidence of wage freezes since 2009, even though this outcome is partially blurred by the fact that the definition of the base wage in 2011 is more comprehensive than in the other years thereby biasing downwards the fraction of wage freezes.
} 
that the 2009 record should not be seen as the result of a point process of adjustment of the wage distribution. Panel B in the same figure makes it very clear that if anything 2009 was in fact the first of at least a row of three years of persistent and increasingly pervasive wage freezing. Data from Social Security Records indicate that for 45.3 percent of all wage-earners the base wage in January 2012 was exactly the same as in January 2011 (in January 2010, the corresponding figure was 29.3 percent).

The huge increase in the share of minimum wages earners amongst full-time workers - from 6.7 percent of total employment in surviving matches in 2006 to 16.6 percent in 2010 - is plotted in Figure 6. In part this increase can be attributed to the real increase of the value of the minimum wage that was agreed upon at the end of 2006 and was not reversed as the recession set in (Carneiro et al., 2011, Pina and Abreu, 2012), but it can also be attributed to the recession itself, the absence of spillover effects in the vicinity of the new minimum being responsible for the bunching of low-pay workers paid above the previous minimum at the new level.

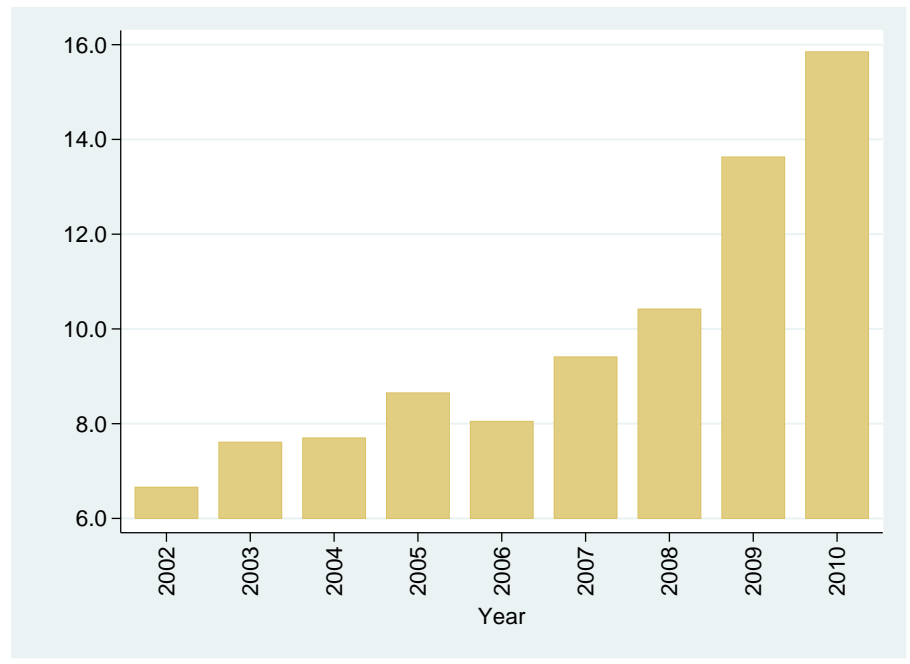

Figure 6: Incidence of Minimum Wages (2002-10)

Source: $Q P$ worker-level data. Sample is restricted to wage earners aged 18 to 61 working at least 120 hours per month and with a monthly wage equal or above the legal minimum in the same year. 
To see how nominal wage rigidity impacts total employment we again estimate on firm data a model of net job creation where we include as independent variables two proxies of downward wage rigidity - the share of the firm workforce that is paid at the legal minimum and the firm-level incidence of wage freezes between year $t$ and $t-1 .{ }^{10}$ We also decomposed net job creation into hires rate and separations rate and estimated the same model taking the two latter variables as the dependent variable. ${ }^{11}$ Results, reported in Table 4, indicate that both nominal wage rigidity proxies are negatively correlated with net job creation and hirings, the correlation being specially strong in the case of the incidence of wage freezes. It is also noticeable that the incidence of minimum wages also increases separations. However, wage freezes have no effect on the separation margin.

TABLE 4: DETERMINANTS OF NET JOB CREATION AND WORKER FLOWS Pooled OLS regression (1987-2009)

\begin{tabular}{rrrr}
\hline \hline & Net Job Creation & Hires Rate & Separations Rate \\
\hline \hline Log sales & $-0.003^{* *}$ & $-0.013^{*}$ & $-0.011^{*}$ \\
& $(0.001)$ & $(0.001)$ & $(0.001)$ \\
Log wages & -0.005 & $-0.064^{*}$ & $-0.059^{*}$ \\
& $(0.005)$ & $(0.005)$ & $(0.006)$ \\
Minimum Wage earners $(\%)$ & $-0.048^{*}$ & $-0.026^{*}$ & $0.022^{*}$ \\
& $(0.004)$ & $(0.003)$ & $(0.001)$ \\
Incidence of Wage Freezes & $-0.160^{*}$ & $-0.160^{*}$ & 0.0001 \\
& $(0.003)$ & $(0.003)$ & $(0.003)$ \\
\hline$R^{2}$ & 0.050 & 0.091 & 0.064 \\
$\mathrm{~N}$ & & 2268854 & \\
\hline \hline
\end{tabular}

Source: $Q P$.

Note: standard errors in parentheses; $*, * *, * * *$ denote

statistical significance at 1,5 , and 10 percent levels.

The regression also includes year dummies.

The negative effect of wage rigidity on total employment is also apparent when we consider the exit margin. Re-estimating the same Probit model as in Equation 2 with the same two wage rigidity proxies in the regressor set. ${ }^{12}$ Results reported in Table 5 show that both the proportion of minimum wage earners at the firm

\footnotetext{
${ }^{10}$ We estimate the same labor demand equation as in Equation 1 but replaced all the interest rate variables in the regressors' set with the two variables proxying for wage rigidity. The model is estimated on $Q P$ data and for that reason firmspecific interest rates, the total amount of outstanding debt,and total factor productivity could not be included as explanatory variables.

${ }^{11}$ Hires occur whenever one worker is at time $t$ employed by firm $f$ but not at time $t-1$. Separations occur whenever one worker is at time $t$ employed by firm $f$ but not at time $t+1$.

${ }^{12}$ Because once again we are using $Q P$ data we cannot include the debt-related variables and total factor productivity considered in the previous sub-section as explanatory variables.
} 
and the incidence of wage freezes are positively and significantly correlated with the probability of the firm shutting down.

\begin{tabular}{rrr}
\multicolumn{3}{c}{ TABLE 5: DETERMINANTS OF FIRM CLOSURE (1987-2008) } \\
\hline & Probit Regression \\
\hline \hline Log Sales & $-0.090^{*}$ & -0.007 \\
& $(0.008)$ & -0.003 \\
Log Wage & -0.034 & 0.018 \\
& $(0.033)$ & \\
& $0.225^{*}$ & 0.019 \\
Minimum Wage Earners (\%) & $(0.021)$ & \\
& $0.236^{*}$ & $(0.013)$ \\
\hline \multirow{2}{*}{ Incidence of Wage Freezes } & $\mathrm{N}$ & 24691349 \\
\hline
\end{tabular}

\begin{tabular}{l}
\hline \hline Source: $Q P$. \\
Note: standard errors in parentheses; $*, * *, * * *$ denote statistical \\
significance at 1,5, and 10 percent levels.
\end{tabular}

significance at 1,5 , and 10 percent levels.

The regression also includes year dummies.

\subsection{The labor market segmentation channel}

Segmentation along contractual types is an essential feature of the Portuguese labor market. As we documented before, temporary contracts represent a large and growing share of total employment. In 2009, the first year to witness a decrease in the share of temporary employment, temporary workers accounted for 28 percent of total employment in surviving firms and 42 percent in newly-created firms (Figure $7)$.

Over the period surveyed here (2003-2008), temporary employment increased twice as much as permanent employment (Table 6). More importantly, workers employed with temporary (fixed-term contracts) bear most of the brunt of employment adjustment. On average, every worker with a temporary contract changes jobs during the course of one year whereas nearly one out of every three workers with permanent (i.e., open-ended) contracts, also switches jobs over the same period of time. ${ }^{13}$ The turnover of jobs filled with temporary (54.9 percent) workers

\footnotetext{
${ }^{13}$ Notice, however, that the rate of worker turnover by type of contract does not control for promotions from temporary to permanent positions, and are therefore higher than they would be if within-firm transitions between types of contracts were excluded.
} 

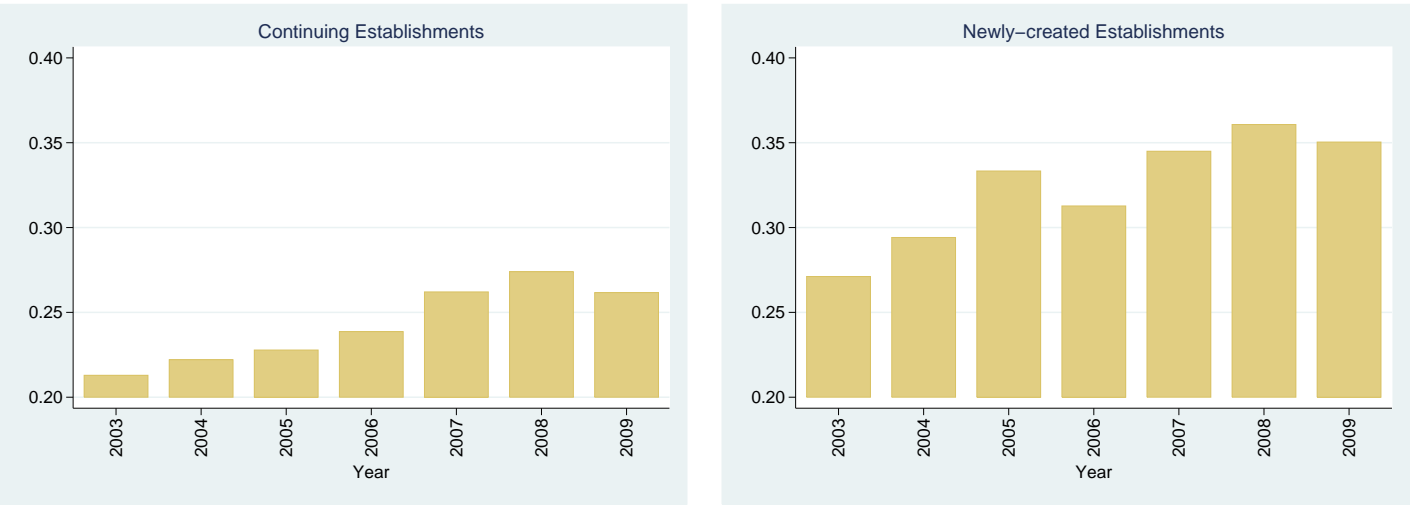

Figure 7: Share of Temporary Employment in Total Employment (2003-2009)

Note: Data from $Q P$.

also exceeds (doubles) that of jobs filled with permanent workers (26.1 percent). Worker turnover in excess of job turnover - i.e., churning - is five times higher for temporary contracts than for permanent contracts. 


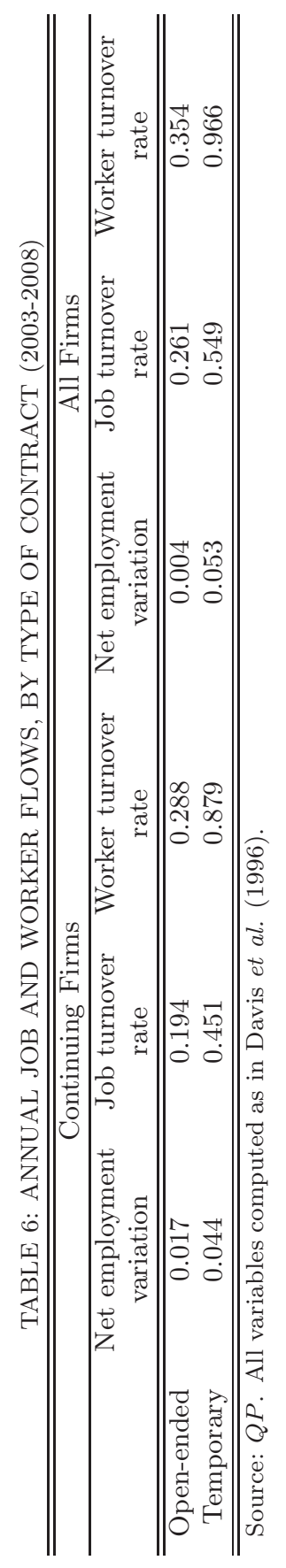


Following Davis et al. (2006), a more clear picture of the relationship between worker turnover and job turnover at the micro-level may be obtained by plotting hire and separation rates on the vertical axis and the firm net employment growth rate, both measured as a percentage of the annual average of the corresponding stock (Figure 8). All lines are well behaved in the sense that the hires and separation rates corresponding to the two types of contracts increase with the magnitude of the variation of net employment and that they are essentially flat to the right of zero in the case of the separations lines, and to the left of zero in the case of the hires line. Independently of the employment regime the firm is in, the hires and separations lines of temporary workers are systematically above, well above in the case of the hires rate, the corresponding line of permanent workers. Both the hires (separations) line of temporary and permanent workers increase with the positive (negative) net employment variation but the gap between the two widens. Consistent with the high churning rate documented above, the hires (separations) rate of temporary workers is always above 20 percent, even if the employer is in the negative (positive) employment variation regime. 


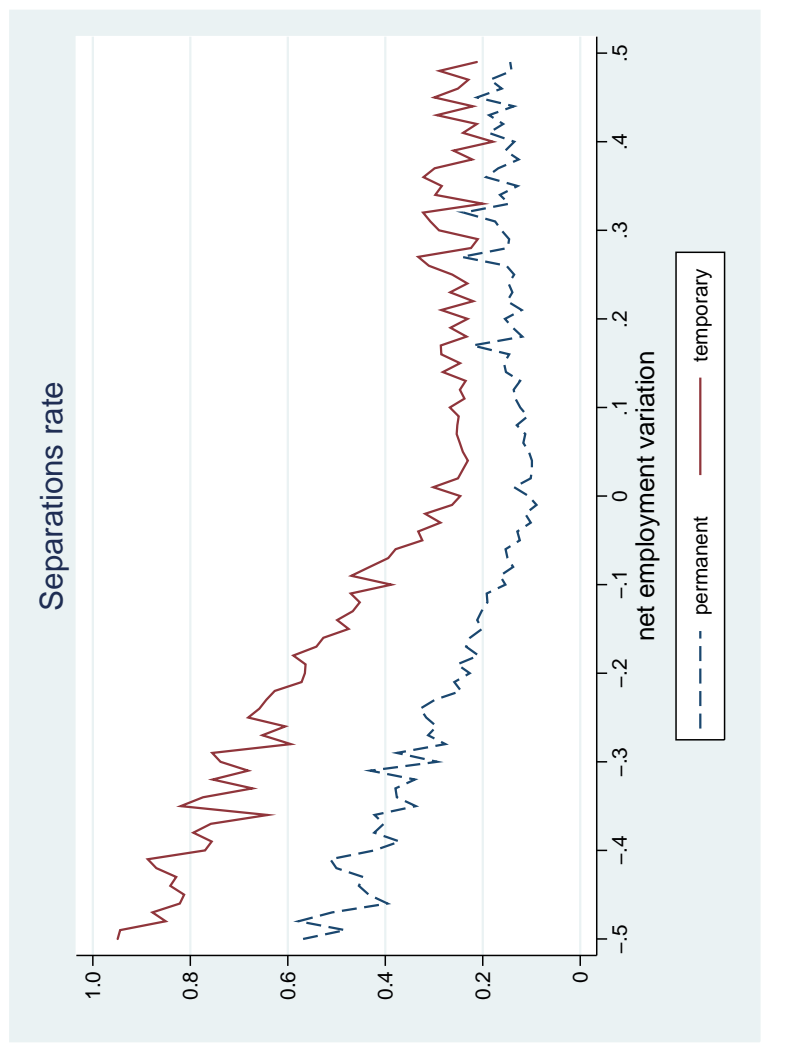

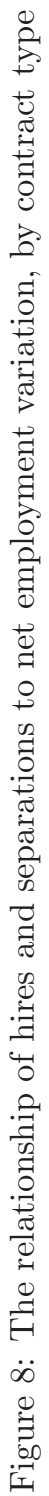

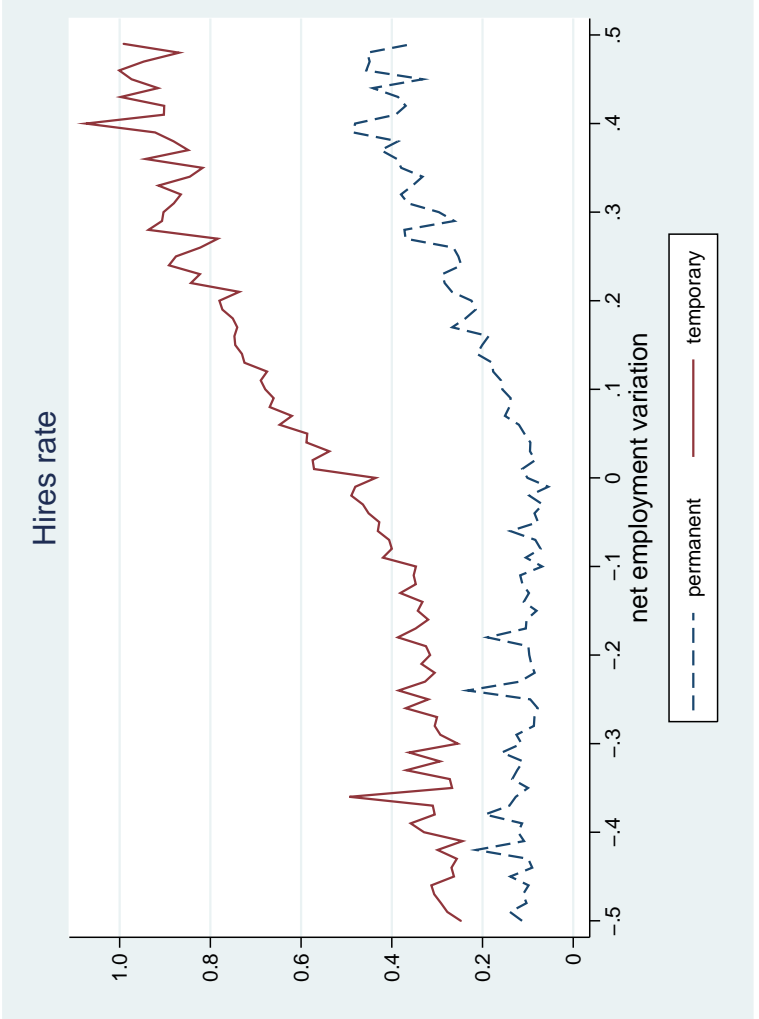


Next, we focus on how firms decompose total employment adjustment (job turnover) into adjustment of temporary employment and open-ended employment (worker turnover for each type of contract). To do that we estimate a parametric model of employment adjustment, as measured by hires and separations rates, assuming that worker flows are linear in the rate of employment change (job turnover). The model is written as:

$$
x_{i t}=\alpha_{i}+\beta_{t}^{n} \Delta l_{i t} I\left(\Delta l_{i t}<0\right)+\beta_{t}^{p} \Delta l_{i t} I\left(\Delta l_{i t}>0\right)+e_{i t}
$$

where $\beta_{t}^{n}$ measures the response of $x$ to negative variations in employment (job destruction) at time $t$ and $\beta_{t}^{p}$ measures the response of $x$ to positive variations in employment (job creation) also at time $t . x$ is replaced sequentially by the hiring rate and the separation rate of temporary, permanent and all workers at firm $i$ in period $t$. $I$ is an indicator variable that takes the value 1 if the condition in brackets is true and 0 otherwise. $l$ denotes total employment. $\alpha_{i}$ is the firm fixed-effect.

The results displayed in Table 7 show that, independently of the employment regime the firm is in (job creation or job destruction regime), the flows of workers of the two types of employment move in the same direction (the hires rate increases and the separations rate decreases as job creation increases, and viceversa when the magnitude of job destruction increases) for both temporary and permanent contracts, but the magnitude of the response in the two margins is quite different. Employers respond to shocks by increasing in absolute terms the hires and separations rate of temporary workers more than they do in the case of permanent workers. Temporary employment shows again as the preferred margin of employment adjustment (positive or negative) acting as the source of flexibility that employers cannot obtain from standard open-ended contracts. Or, differently put, temporary workers bear most of the brunt of employment adjustment. 


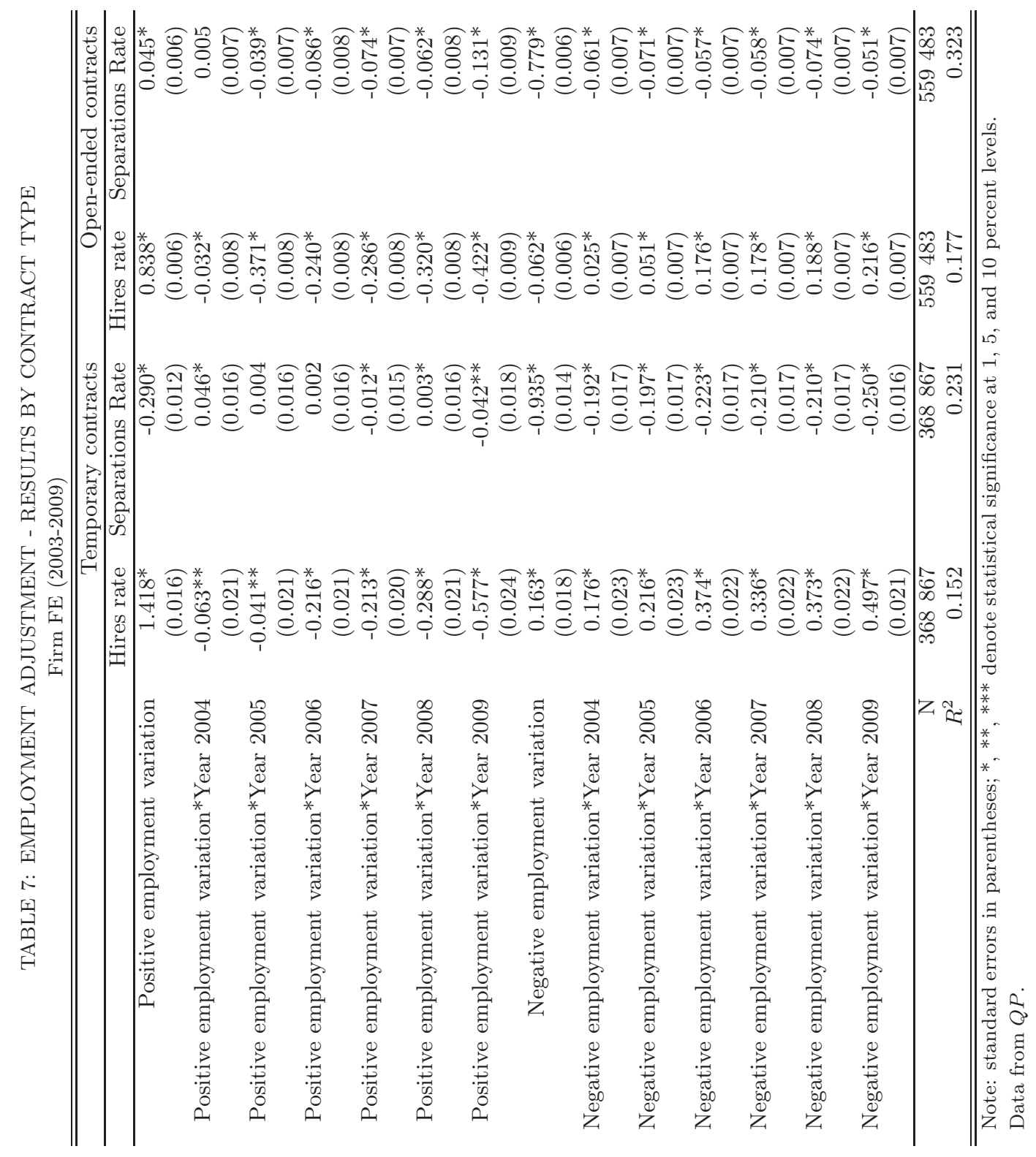


The estimates of the coefficients of the interaction between the employment variation and the year dummies futher indicate that as we approach 2009 both the hires and the separations rate become more responsive to negative employment shocks, with greater declines in the hires rate and greater increases of the separations rate. Again, the effect is larger for temporary contracts on both margins.

\section{Conclusion}

Severe macroeconomic imbalances and inappropriate labor market institutions impaired the Portuguese economy ability to cope with the consequences of the 2008 global crisis. As the financial crisis turned into a sovereign debt crisis, the labor market response originated huge social costs associated with catastrophically high job destruction rates, record high unemployment rates, and massive long-term unemployment. Differently put, the depth of the recession exceeded the resilience of the labor market, i.e., its ability to weather economic downturns with limited social costs.

The response was characterized by a large fall of job creation both at the instensive and extensive margin. Yet, it was on the job destruction margin that

the response differed the most from past recessions. Especially along the exit margin, an unprecedented amount of job destruction occurred, shutdowns being responsible for nearly half of the total job destruction in 2009.

We conclude that the severity of credit constraints played a significant role in the current job destruction process. The worrying consequences of credit market fragmentation appear to have been translated into a sharp drop in the average amount of bank debts by Portuguese firms. We provided evidence showing that the firms that faced higher financial costs exited or destroyed jobs at higher rates than those that operated under less stressful financial conditions, most notably in 2010 and 2011.

Wage rigidity was seen to be associated with lower net job creation and higher failure rates of firms. The current recession is marked by a huge increase of the proportion of workers paid at the legal minimum wage (which was considerably 
raised in the early years of the recession), and by the freezing of nominal wages for nearly one third of all workers that did not switch jobs in 2009, and about $45 \%$ in 2012. The observed incidence of wage freezes for stayers is evidence of high nominal wage rigidity, wage cuts being introduced via firm turnover (and displacement), not within surviving firms or matches.

Finally, labor market segmentation seemed to have favored stronger job destruction that was facilitated by an increasing number of temporary workers. Temporary employment contracts were the primary source of employment adjustment, especially on the expansionary margin.

For decades, the Portuguese labor market operated in a fragile equilibrium characterized by a very large portion of low-qualified, low-wage, low-productivity jobs. Many of those jobs, which survived due to firm-specific human capital investments, were destroyed with the event of the financial crisis and the adjustment program under way. The workers displaced from those jobs face near insurmountable prospects to find a suitable job. Retraining of unskilled workers (in a large scale) and employment policies aimed to facilitate hires of low-wage workers (e.g., permanent social security reductions or tax credits on labor income) seemed to be justified. On the labor segmentation front, the arguments in favor of a single contract for new hires are increasingly gaining support (Bentolila et al., 2012). Reducing the employment security gap between insiders and outsiders is likely not only to reduce excessive churning, but also to improve firm-specific investments, by employers and employees, and thus productivity growth. The fragmentation of the credit markets is imposing a serious threat to the survival of Portuguese firms. This problem, which is common to other countries, arguably needs to be addressed urgently by European decision makers (Reichlin, 2013). 


\section{Appendix 1}

\section{Data description}

\section{A. Simplified Business Information (Informação Empresarial Simplifi- cada) - IES}

IES is an administrative dataset that gathers information reported by businesses for statistical purposes, but also for the purposes of tax administration, business registry, and financial supervision.

Every year, each firm has to report information covering different areas of their activity from corporate restructuring, to production and employment, and annual accounting and tax statements. Reporting is mandatory and penalties apply in case of non-compliance. All information must be reported on-line, as a rule, until June 30 .

Data are considered to be accurate for a number of different reasons: (i) they are reported in a single coherent operation with multiple automatic editing rules that ensure the consistence of the information; (ii) the Statistics Portugal Agency monitors the quality of the data, regularly checks with the respondents their accuracy of the information, and corrects any data missreported.

On average, every year about 350 thousand firms report information to the database.

\section{B. Personnel Records (Quadros de Pessoal) - QP}

QP is an annual mandatory employment survey collected by the Portuguese Ministry of Employment that covers all establishments with wage earners. Every year, all employers with wage earners are legally obliged to fill in a standardized questionnaire. Currently, the dataset contains yearly information on about 350,000 firms, 400,000 establishments and 3 million employees. Data are available on each establishment (location, economic activity, and employment), the firm with which it is affiliated (location, economic activity, employment, sales, and legal framework) and each and every one of its workers (gender, age, educa- 
tion, skill, occupation, tenure, earnings, and duration of work). The information on earnings is very detailed and complete. It includes the base wage (gross pay for normal hours of work), regular benefits, irregular benefits, and overtime pay, as well as the underlying mechanism of wage bargaining. Information on standard and overtime hours of work is also available. The dataset is longitudinal in nature. Each firm/establishment entering the database is assigned a unique identifying number and the Ministry implements several checks to ensure that a unit that has previously reported to the database is not assigned a different identification number. This dataset allows us to compute measures of job turnover and the shares of employment creation and destruction accounted for by the entry and exit of establishments/firms. All these variables may be computed from $Q P$ establishment/firm-level files. Since year 2000, the data set also contains information on the type of contract - regular or fixed-term -, making it possible to compute job and worker turnover measures separately for the two types of contracts. 


\section{Appendix 2}

Wage Variation and Wage Drift 


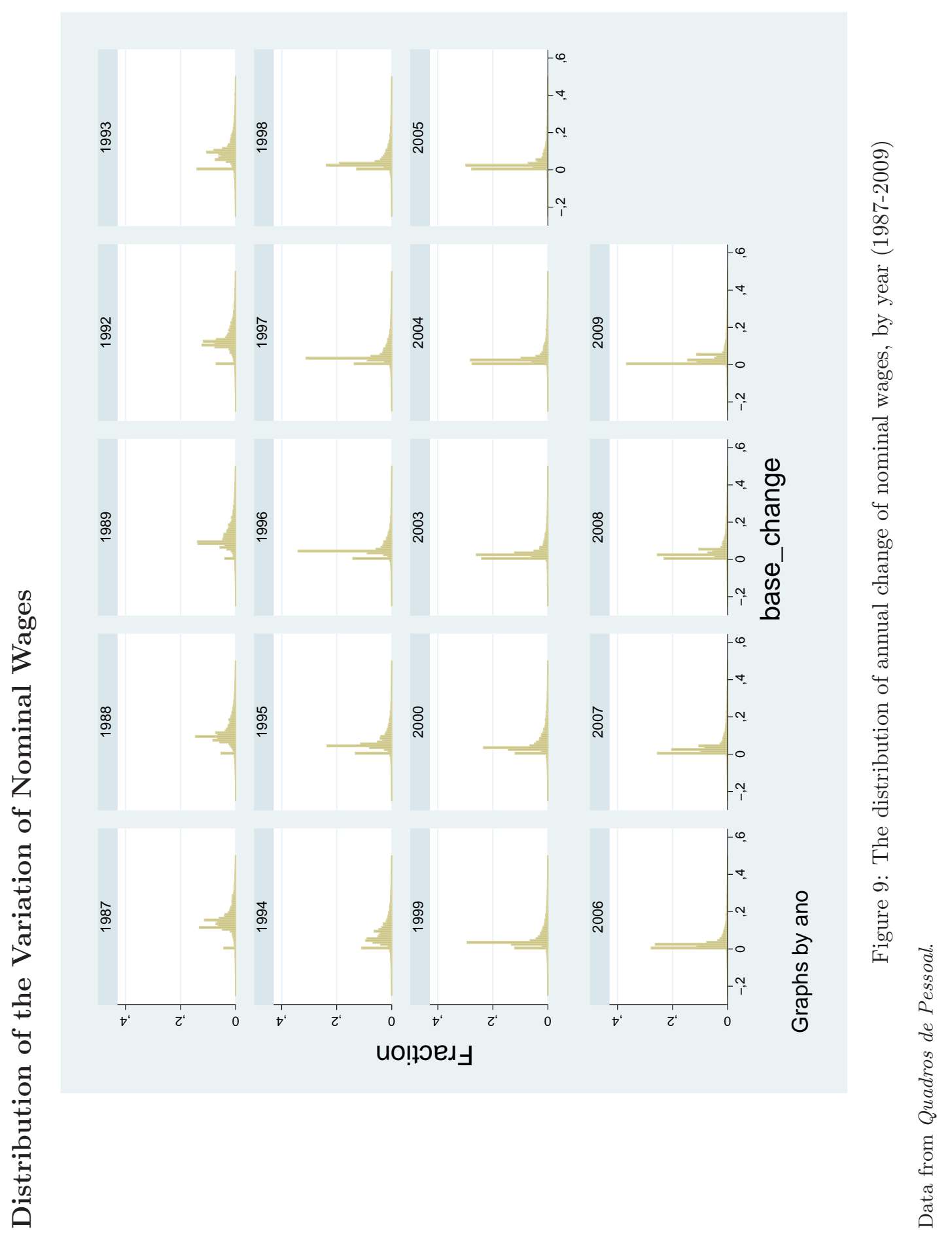




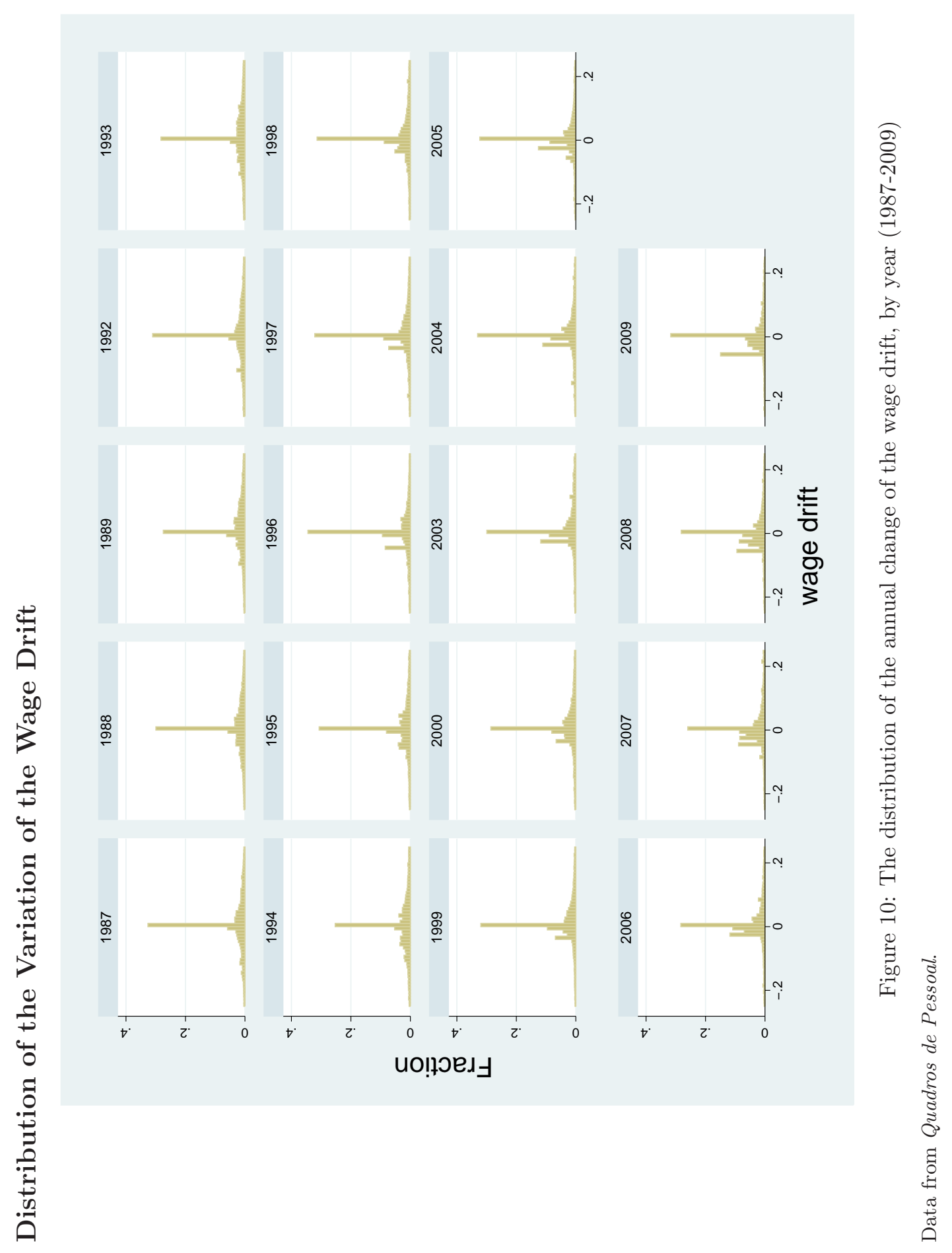




\section{References}

Addison, John T., And Pedro Portugal (2008), How Do Different Entitlements to Unemployment Benefits Affect the Transitions from Unemployment into Employment?, Economics Letters, 101: 206-209.

Addison, John T., Mário Centeno and Pedro Portugal, (2009), Do Reservation Wages Really Decline? Some International Evidence on the Determinants of Reservation Wages, Journal of Labor Research, 30: 1-8.

Bentolila, Samuel, Pierre Cahuc, Juan J. Dolado and Thomas Le Barbanchon, (2012), Two-Tier Labour Markets in the Great Recession: France Versus Spain , Economic Journal, 122: F155-F187.

Blanchard, Olivier (2007), Adjustment Within the Euro; The Difficult Case of Portugal, Portuguese Economic Journal, 6: 1-21.

Blanchard, Olivier, and Daniel Leigh (2013), Growth Forecast Errors and Fiscal Multipliers, IMF Working Paper, 13/1.

Blanchard, Olivier, and Larry Summers (1986), Hysteresis And The European Unemployment Problem, NBER Macroeconomics Annual 1986, Volume 1: 15-90.

Blanchard, Olivier and Pedro Portugal (2001), What Hides Behind an Unemployment Rate: Comparing Portuguese and U.S. Labor Markets, American Economic Review, 91: 187-207.

Cardoso, Ana Rute and Pedro Portugal (2005), Contractual Wages and the Wage Cushion under Different Bargaining Settings, Journal of Labor Economics, 3: 875-902.

Carneiro, Anabela, Carla Sá, João Cerejeira, José Varejão and Miguel Portela (2011), Estudo sobre a Remuneração Mínima Mensal Garantida em Portugal - Relatório Final, Lisboa: Direção Geral do Emprego e das Relações de Trabalho. 
Carneiro, Anabela, Paulo Guimarães, And Pedro Portugal (2012), Real Wages and the Business Cycle: Accounting for Worker, Firm, and JobTitle Heterogeneity, American Economic Journal: Macroeconomics, 4: 133152.

Davis, Steven J., John Haltiwanger, And Scott Schuh (1996), Job Creation and Destruction, Cambridge (Ma): MIT Press.

Davis, Steven J., R. Jason Faberman And John Haltiwanger (2006), The Flow Approach to Labor Markets: New Data Sources and Micro-Macro Links, Journal of Economic Perspectives, 20: 3-26.

Elsby, Michael, Bart Hobijn, And Aysegul Sahin (2008), Unemployment Dynamics in the OECD, NBER Working Paper 14617.

Franco, Francesco (2013), A Projection of the Market Based Adjustment Path of the Portuguese Economy, mimeo.

Jolivet, Gregory, Fabien Postel-Vinay, and Jean-Marc Robin (2006), The Empirical Content of the Job Search Model: Labor Mobility and Wage Distributions in Europe and the US, European Economic Review, 50: 877-907.

LuUngqvist, Lars And Thomas J. Sargent (1998), he European Unemployment Dilemma, Journal of Political Economy, 106: 514-550.

Nickell, Stephen And Daphne Nicolitsas (1999), How Does Financial Pressure Affect Firms?, European Economic Review, 43: 1435-1456.

Nickell, Stephen, And Daphne Nicolitsas (1999), How Does Financial Pressure Affect Firms?, European Economic Review, 43: 1435-1456.

OECD (2012), Employment Outlook, Paris: OECD Publishing.

Pina, Álvaro And Ildeberta Abreu (2012), Portugal: Rebalancing the Economy and Returning to Growth Through Job Creation and Better Capital Allocation, OECD Economics Department Working Papers, No. 995. 
Portugal, Pedro, Anabela Carneiro, and Paulo Guimarães (2010), On the Cyclical Sensitivity of Real Wages, Banco de Portugal - Economic Bulletin, Winter 2010: 87-99.

Raposo, Pedro, Pedro Portugal and Anabela Carneiro (2013), The Sources of the Wage Losses of the Displaced, mimeo.

Reichlin, LuCReZia (2013), Monetary Aspects of the Euro-Area Crisis, Journal of Macroeconomics, this issue.

Torres, Sónia (2010), Unemployment, Worker Flows and Wage Formation in the Portuguese Labour Market, University of Porto, PhD Thesis. 